\title{
Total Quality Management in Higher Education: A Review
}

\author{
Mohammed Hasan. In'airat \\ Dept. of Business Administration, Ibn Rushd College for Management Sciences \\ PO Box 447, Abha 61411, Saudi Arabia \\ E-mail: mhsaleh65@hotmail.com
}

Amer Hani Al-Kassem

Dept. of Tourism, Ibn Rushd College for Management Sciences

PO Box 447, Abha 61411, Saudi Arabia

E-mail: drameralkassem@yahoo.com

Doi:10.5296/ijhrs.v4i3.6368

URL: http://dx.doi.org/10.5296/ijhrs.v4i3.6368

\begin{abstract}
Total Quality Management (TQM) is a perception, which educational institutions can only attain through long period of planning, by the formulation and execution of annual quality program, which substantially moves towards the accomplishment of the vision. Application of TQM concepts is one of such degree, which will go a long way in reviving the higher education system. This study endeavors to analyze TQM in higher education and outline the literature on Critical Success Factors (CSF) and its execution in all areas. The study concludes the CSF and its execution in higher education institutions. Some institutions already enjoyed the advantages of TQM methods in their programs with determination and strict adoption of the system to achieve their goals. The insight of this review is giving feedbacks of the recent studies on how TQM system will be able to utilize different instruments and hypothesis to legitimize employees, create a positive friendly environment and highlight the necessity of the students to bring out the best in them.
\end{abstract}

Keywords: Total Quality Management (TQM), Critical Success Factor (CSF), higher education

\section{Introduction}

Determining quality in education is a monumental exception considering the underlying beneficiary is us, Humans. It is the quality of education that shapes incessant wealth and security of both societies and their people (Babbar, 1995). What is really the relevance of education for the evolution of brilliance and proficiency of a person that will lead to a progressive economy should not be subverting. This has used a powerful scheme for the improvement of higher education in almost all countries all over the world. The higher educational system was proven effective in producing remarkable professionals to rule the 
nation in the future. But then, quality improvement is a constant process. Thus, perception on index rate and execution is necessarily precedent (Murad \& Rajesh, 2010). In order to enhance quality service, educational institution needs to know the necessities. These necessities, must be understand the essence of the characteristics. However, people foresee quality variously. Owlia and Aspinwall (1997) specify that in order to give verdict to quality, and correspondingly improve quality, it is vital to find out the characteristics of quality. Thus, it is crucial to determine the characteristics of quality for the measurement of the education process (Cheng \& Tam, 1997).

TQM means handling of all the components of organization principles and procedures, patterns, arrangement, and all those who are affected in any way with the quality of the product or service (Stanciu, 2003). The main objective of TQM is to generate within the organization an environment in which all the assets are used ingeniously and effectively in order to provide quality service the institution needs to adapt in this fast paced world (Vinni, 2011). TQM has been acquired as a management epitome by many organizations worldwide. Quality movement started with quality improvement project at manufacturing companies. But afterwards it dispersed to other service organizations including banking, insurance, nonprofit organizations, health care, government and educational institutions. TQM molds rooted on imparting of prime instructors, more often than not, demands a number of rules such as cooperation, top management leadership, customer focus, employee engagement, consistent advancement tool, trainings, etc. (Murad \& Rajesh, 2010).

The higher education sector at both government and institution level has been progressively introducing high quality management systems over the last two decades, the urge for accurate quality measure and security methods has been increased boost swiftly. Most especially in the USA and Europe, as well as in the Middle and Near East, Africa, China, South East Asia, the UK, Australia and New Zealand (Srikanthan \& Dalrymple, 2003; Haug, 2003; Materu, 2007; Brookes \& Becket, 2007). At the same time, huge funds from governments makes it very crucial for those who handle education to guarantee that education provided in schools, universities and institutions of learning will be fruitful. Furthermore, some other circumstantial demand called for more competent and exceptional quality of learning. These consist of developing surroundings in the figure of students, intensifying clash in higher education institutions, intensive challenges to students, and more adaptable programs for both in undergraduate and graduate level (Becket \& Brookes, 2006).

Nevertheless, the education sector is not completely comfortable with the TQM method. Schools thought that TQM methods are not suitable for them having the fundamental concept of "Customer Satisfaction" they felt uneasy with the thought of them just pleasing their students who are their valuable customers (Barnard, 1999). Alternatively, schools can use the quality method such as the European Foundation for Quality Management (EFQM) excellence model, ISO 9000, Malcolm Baldrige National Quality Award to boost-up the students' performance. Even the most known service quality procedure, SERVQUAL (Parasuraman et al., 1985; 1988), is also used to calibrate the quality in the education context. Models and concepts, such as EFQM, Singapore Quality Award (SQA), School Excellence Model (SEM) and Malcolm Baldrige National Quality Award (MBNQA), are widely used to educational institutions. These posers adopt the methodology of TQM which has been 
adjusted for the school environment. Most schools and universities recognize the welfare of these quality models, and comprehensive research has been done in this area to investigate the school performances in relation to the quality management philosophy.

This has led to a substantial deliberation within academic institutions on the essence of such systems to higher education. Antagonist aim on concerns about the parameters to academic freedoms, risk averse processes that may restrain diversity and the evolution of managerialism, or the bloom of administrative control, when in fact advocates alluded the advantage of potent change management, constant progressive cycles, higher academic standards, increased staff and students' fulfillment and cutting edge planning (Hoecht, 2006; Mizikaci, 2009; Williams, 2009).

This research aims to determine how quality is acknowledged by diverse groups of people, namely the students, parents, faculty members and employers, regarding the effectiveness of TQM in Higher Education. The perception acquired from the study will configure the benchmarking with TQM methods which will lead to focus the general principles of TQM. It will also stimulate the question on how these methods can be used to boost the quality of an academic institution, which is the primary purpose of this work.

\section{Literature Review}

\subsection{Understanding Total Quality Management}

TQM has many definitions. Masters of the TQM like Deming, Juran, Crosby, Ishikawa and Feigenbaum characterized the theory in various ways but still the significance and soul stays the same. According to Deming, "quality is a consistent quality development procedure towards anticipated degree of consistency and perseverance. Deming also describe 14 fundamentals of quality management to boost project outputs and achievement of the organization. Juran identified quality as "fitness for use". According to him, each individual in the organization should participate in the exertion to make products or services that are fit for use. Feigenbaum defined total quality as consistent work procedures, beginning with customer necessities and finalizing with customer's satisfaction (Evans \& Dean, 1999). Crosby defines quality as a correspondent to demands. He focalizes on zero defects and setting things straight by doing it correctly the first time. Ishikawa (1985) also accentuate on the relevance of total quality control to boost organizational performance. According to him, quality does not mean the quality of product only, but also of the quality of management, or the reputation of the company.

Definitions of quality has been altered with the transition of time, modification of customer's needs and demands. But the vitality has more or less been progressed to resolve the issue, compliance to standards for customer satisfaction. With management routine getting complicated, attacks to managing quality in operational areas are becoming unmanageable. Institutions which have victorious outcome with TQM principles have customer and quality integrated in their corporate scheme (Jha and Joshi, 2007). Any institution is a system of interconnected units. For TQM to be victorious, all of the elements within the organization must be conjointly engaged.

Some characteristics of TQM are considered to be fundamental: modification, customer preference, communication, consistent improvement, restorative measures, the organizational 
structure of network type in the process or case management, creativity, IT, organizational culture, team and future orientation (Vinni, 2011). While the critical factors are the basis for transformational preference to produce a substantial advancement culture for consistent competitive advantage. But basically, the main objective of TQM is to generate within the organization an environment in which all the assets are used ingeniously and effectively in order to provide quality service the institution needs to adapt in this fast paced world. TQM is a way of managing to amend the efficiency, viscidity, adaptability and aggressiveness of a business in general. As specified by British Standard Institution, TQM is compose of a "management doctrine and company patterns which intent to rein the human and material resources of an organization in the most efficient way to attain the goal of the organization" (Zakuan et al., 2012).

\subsection{Importance of Total Quality Management}

In an aggressive environment, organizations are compelled to develop and apply methods within global context. TQM has been distinguished as a management doctrine and a belief that has support many organizations progress towards reaching splendid businesses. TQM aids in making a culture of trust, cooperation, teamwork, quality-mindedness, eagerness for consistent advancement, continuous learning and eventually, a working environment that imparts to a firm's success and existence (Yusof \& Aspinwall, 2000). TQM is the process of modifying the essential culture of an organization and channeling it towards superior product or service quality (Gaither, 1996). It also focuses on customer satisfaction through a concept of "continuous improvement" that will lead to joyous victory. As a general management TQM is identified as philosophy and a set of instruments which grants an institution to follow an outline of quality and a way for achieving quality, with quality being a consistent development determined by customers' satisfaction with the services they have experience (Michael et al., 1997).

TQM has been greatly acknowledged and victoriously applied in many small and large organizations, providing them the advantage in international as well as local competence through the creation of high quality products or service to fulfill the customers demand (Dale \& Plunkett, 1990). As Lakhal et al. (2006) indicate that organizations with TQM systems in place coherently surpass the industry criterion for return on investment. While, Saad and Patel (2006) reasoned that by enforcing TQM, the companies acquired in-depth discernment of the key element related with the quality supply chain function practices in Indian automotive industries. They also proved that TQM in supply chain is significant to ameliorate key elements such as quality, delivery and lead-time. Besides that, Jun et al. (2006) showed that the firms with human resources that concentrate in TQM methods can raise employee satisfaction. The striking improvements in employee satisfaction resulted to a higher level of customer's devotion. The summary of previous researches is shown in Table 1. 
Table 1: Summary of Previous Researched

\begin{tabular}{|c|c|c|c|}
\hline Authors & Title & Findings & $\begin{array}{c}\text { Locatio } \\
\mathbf{n}\end{array}$ \\
\hline $\begin{array}{l}\text { Jiju Antony } \\
\text { et.al } \\
(2002)\end{array}$ & $\begin{array}{l}\text { Success factors of TQM } \\
\text { implementation in the } \\
\text { industry an industry-Hong } \\
\text { Kong. }\end{array}$ & $\begin{array}{l}\text { 1.1.1 Elements that determines the } \\
\text { success of TQM executions in } \\
\text { organizations in Hong Kong is a } \\
\text { dedication of management, the role of } \\
\text { quality department, training and } \\
\text { education, employee engagement, } \\
\text { consistent improvement. } \\
\text { 2.1.1 A close connection with } \\
\text { suppliers, product design and service, } \\
\text { quality policy, quality of data and } \\
\text { reports, communications and } \\
\text { customer satisfaction orientation }\end{array}$ & $\begin{array}{l}\text { Hong } \\
\text { Kong }\end{array}$ \\
\hline $\begin{array}{l}\text { Mile } \\
\text { Terziovski } \\
\text { and Danny } \\
\text { Samson } \\
(1999)\end{array}$ & $\begin{array}{l}\text { The relationship between } \\
\text { implementation of TQM } \\
\text { practices with } \\
\text { organizational } \\
\text { performance in various } \\
\text { sectors and organization } \\
\text { sizes }\end{array}$ & $\begin{array}{l}\text { TQM has a positive relationship to } \\
\text { performance and business operations, } \\
\text { employee relations and customer } \\
\text { satisfaction. }\end{array}$ & $\begin{array}{l}\text { Various } \\
\text { Sectors }\end{array}$ \\
\hline $\begin{array}{l}\text { Bishnu } \\
\text { Sharma and } \\
\text { David } \\
\text { Gadenne } \\
(2001)\end{array}$ & $\begin{array}{l}\text { Importance and } \\
\text { effectiveness of quality } \\
\text { management approach }\end{array}$ & $\begin{array}{l}\text { - Many business firms in Australia } \\
\text { implemented ISO } 9000 \text { and TQM in } \\
\text { maintaining the quality level of } \\
\text { production and services. }\end{array}$ & Australia \\
\hline $\begin{array}{l}\text { M. Sadiq } \\
\text { and Boon } \\
\text { Hoong } \\
(2003)\end{array}$ & $\begin{array}{l}\text { The implementation of the } \\
\text { TQM and organizational } \\
\text { performance of small and } \\
\text { medium companies in } \\
\text { Malaysia with or without } \\
\text { ISO } 9000 \text {. }\end{array}$ & $\begin{array}{l}\text { - ISO } 9000 \text { had a positive impact on } \\
\text { organizational performance. } \\
\text { - ISO } 9000 \text { as a catalyst to increase the } \\
\text { performance of organizations } \\
\text { implementing TQM. }\end{array}$ & Malaysia \\
\hline
\end{tabular}

Source: International Journal of Academic Research in Business and Social Sciences, 2012, Vol. 2, No. 12

\section{Important Factors in Total Quality Management}

TQM is a cooperative, standardized approach in preparing and administering a steady organizational improvement process. Its manner is focused on surpassing customers' expectations, defining the issue, building trust and devotion, and advocate open decision-making among employees. There are five major steps to TQM, and each are vital to have a victorious implementation (Napierala, 2012). 


\subsection{Commitment and understanding from employees}

It is a key to guarantee that all employees within organizations should be aware about the TQM rules and make them a crucial part of their work. Employees should be aware of corporate goals and identify the significance of these goals to the comprehensive achievement of organization. Employees should understand what is expected from them and why. It may sound like an easy-task but too often this is not achieved by management. When employees understand and share the same perception as management a world of possibilities is released. If they are unaware, responsibility is impaired and policies will not be triumphantly deployed.

\subsection{Quality improvement culture}

The organizational culture required to be regenerated on a consistent basis to inspire employee evaluation. Employees are full of beneficial observation and pay attention to those administering the procedures that keep business running. If employees have any concept on how to have better operations, they need to be aware in management courtesies to impart their ideas so we can utilize it.

\subsection{Continuous improvement in process}

There is no room to be stagnant. If employees are not improving, then they are moving backwards. TQM is a consistent advancement process and not a program. This requires continuous progress in all the associated policies, procedures and controls organized by management. Organizations should be an observant to the market and make an exertion to habitually modify all angles of your operation. There should be a consistent struggle to improve competency which will sum up to steady extent for improvement.

3.4 Focus on customer requirements

In today's market, customers demand and anticipate perfect goods and services with zero defects. Concentrating on customer demands is important for lasting survival and necessary in order to have close relationships with customers. People do business based on emotion. Rivals will always be a danger. Maintain a happy and peaceful customer relation. Make sure definite demands of all customers are well recorded and accepted by everyone that access the account.

\subsection{Effective control}

It is vital to oversee and evaluate the performance of the business. It's easy to bury how many times in a year an employee does not adapt to a restrained procedure. If rigid documentation is sustained, employee will be able to subjectively measure areas for advancement and concentrate on endeavor where they will give an outstanding return of both time and financial resources. Empirical literature opined that TQM is combination of diverse procedure. Today's ever changing economic market demands organization to continuously exceed expectations, and workers requires being more than an observer in decision making (Napierala, 2012). Now since the main objective of this study is to know TQM effectiveness in academic institutions we should study its effectiveness on the five components of service for students namely, physical environment and resources, human resources, process and products. Also to know which TQM components are vital in development? Take note of good practice and stimulate areas where advancement and progress will be of gain. Adams (1993) further introduce in an article at UNICEF that quality education consists of elements like:

- Students are in good condition, sustained well, willing to cooperate and determined to study and backed-up well by their families and society. 
- Environment is distinguished as in good condition, free from harm, keen on gender and maintain sufficient resources and facilities.

- Contents are showing in significant syllabus and materials.

- Methods in which skilled trainers apply child-centered training techniques and competent evaluation to promote education and lessen discrepancy.

- Outcome which comprises intelligence, competence, and philosophy that are associated to national aspiration for education and embrace positive cooperation in community.

As what Crosby (1999) asserts, "The first exact definition of quality is conformance to requirements". The concept of quality in TQM is associated and this interpretation helps it not to be misinterpreted as characteristics of product or service but rather something which is assigned to it and evaluate only when an institution's services passed the standards that has been given. ISO (International Organization for Standardization) interprets TQM as a management technique for an organization, which focus on quality basing in cooperation off all members that targets lasting victory through customer fulfillment and profits to all members of organization and to community. Burnham (1997) have infuse a representational components acquired from the hypothesis and methods of TQM as they might be used to academic institution to administer the guiding fundamentals required for educational reform.

\section{Advantages and Disadvantages of TQM Strategies}

According to Kelchner (2008), TQM is a system of constant development that includes all workers from top management down to production line workers. The focal point of the program is to upgrade customer service and lessen waste in business. Quality development team use problem-solving methods and research to be knowledgeable and decrease weaknesses in the company or institution. But of course in every system or program there would always be advantages and disadvantage. She interprets TQM strategies as follows:

4.1 Production disruption

Executions of TQM system in an institutions demands comprehensive training of employees. The employee training compose of information in problem solving techniques and the tools to appraise a procedures and verify deficiency such as statistical process control, Pareto diagrams and brainstorming techniques. During the initial training period, productivity can drop. Communication for quality developing teams also takes workers away from their duties, which also lessens productivity. While the development do weaken lead time, eliminate waste and improve productivity, the beginning stages of implementing TQM in an organization can weaken the worker productivity.

\subsection{Lower production cost}

TQM program eradicate defects and waste, which lessen production costs in a business. As team members assemble to recognize faults and issues are spotted and sorted quicker than when ousting weaknesses in the business, the company continues to enjoy lessen costs and higher profit. Quality development teams can remove defects (zero defects), lessen lead time and verify redundancies in the production process that can significantly add to the profit the company earns. 


\subsection{Employee resistance}

TQM demands revision in mindset, character and techniques for exhibiting their jobs. When management does not efficiently convey the team approach of TQM, workers may become doubtful, which leads to employee resistance. When workers resist the program, it can decrease employee confidence and productivity for the business. TQM uses small accumulative developments to progress the business forward. It can take years for a company to adore the advantage of the program.

\subsection{Employee participation}

Once workers figure out their attendance and cooperation in TQM is vital to its victory, self-confidence and productivity increase. Workers become advocates through cooperation on quality improvement teams. Businesses can increase morale further by acknowledging developing teams that make significant improvement in the production procedure to lessen or eliminate waste.

\section{Critical Success Factor}

There are numerous substantial matters that capture your concentration in business that it's often difficult to identify the things that really matter for success. What's more, it can be insanely challenging to get everyone in the team driving in the same path and targeting on the true essentials. That's where Critical Success Factors (CSF) comes into the rescue. CSF are the vital areas of exercise that must be carried out well if you are to accomplish the goal, target or aim for your business or project. By being aware of your CSF, you can establish a probable point of attribute to guide you handle and evaluate the progress of your business or project. As a trivial point of reference, CSF assists the team to learn exactly the crucial part of the business or project. In this manner, it aims to motivate the people to execute their own job in the right context and climb up on the same goal (Gallo, 2011).

Rockart (1979) defines CSF as the definite number of areas in which outcome, if they are sufficient, will guarantee a prosperous competitive action for the organization. They are the few important areas where things must head the right way for the business to prosper. If outcome in these areas are not sufficient, the organization's work for the time being will be less than expected. He also derived that CSF are field of activity that should acquire consistent and precise treatment from management. Direct engagement of higher management grants all agreements to be made expeditiously and safeguarding TQM journey. Top managements advocacy is vital to confirm the availability of detailed actions (Crosby, 1979). According to Saraph et al. (1989) the activities can be taken to organize the divisional top management and quality policy, provide a quality management structure, captivate a whole staff, publicize information on quality, process management operating quality and systematize the day of quality.

According to Abdul-Aziz (2002) management is dedicated to be constantly mindful of required development. Amidst the obligation that should to be emphasized is to restore and amend key components of the organization, create fundamental development in the organization, formulate a new job specification, settling struggles to be faced, to guarantee the cooperation of members and create an adequate plan to upgrade the administration of an organization. In order to publicize quality strategy across the organization, top management should create an 
organizational atmosphere that centralizes on constant development. Their dedication advocates the creation of precise and discernible quality values, along with a management system to facilitate all activities of the company towards quality excellence (Rao et al., 1997). Critical Success Factors are vigorously associated to the mission and critical goals of business or project. Whereas the mission and goals concentrate on the objectives and what is to be attained, Critical Success Factors eyed on the most essential areas and get to the very center of both what is to be attain and how you will achieve it (Manktelow, 2011).

\section{Total Quality Management In Higher Education}

Education plays a vital part in a person's achievement, apart from inborn talent. Education will mold and guide a person to be what they want to be. Of course, if discussing education, teachers will play a very important role. Teacher has many responsibilities not only to the students but also to the society. Now in the $21^{\text {st }}$ century, a time when technology is at its peak, education faced a deep challenge to adopt on fast paced world. Changes in global educational settings have compelled the institutions of higher learning to revolutionize its activity. Teachers must follow through in learning new techniques or methods in their teaching for the benefit of the students and society as a whole. The aggressive business environment leads the collaborator of the educational sector to require for more dependable, ingenious, and multi-skilled \& knowledgeable work force. These have imposed the higher education institutions to be more interested on quality educational system (Ariff et al., 2007).

Sangeeta et al. (2004) regards education system as a development process consisting of observations of students, instructors, administrative staff, physical facilities and procedures. The procedures compose of teaching, learning, and administration. While, output consist of examination outcome, employment, profit, and satisfaction. According to Roffe (1998), because of an open competition, students are now turning more to customers as well as consumers and anticipate to pay an increasing due of education cost. This resulted to competition causing generating different programmers for different student groups. The abstract issues consider whether TQM in higher education should be people or problem adjustments, trouble in presenting the implementation and acceptance of TQM in higher education institutions, which have not accepted dogma of TQM, group versus single preference towards TQM, and sustaining the range of invention amongst others.

TQM is a philosophy and system for continuously improving the services and/or products offered to customers (Fitzgerald, 2004). Now that the technologies of transportation and communication have substituted national economic systems with a global economy, nations and businesses that do not implement TQM can become globally non-competitive quickly. This matter towards non-competitiveness can be prevented if societies are trained to become TQM advocates. Therefore, the possible advantages of TQM in educational institutions are very clear like:

- TQM will support educational institutions to create an upgraded service to its customers namely the students and employers.

- The consistent improvement focus of TQM is an essential component for satisfying the accountability essential to educational reform.

- Executing a no-fear TQM system offers more exciting challenge to students and teacher 
to empower teamwork and cooperation with one another. In that way, each observation can be utilized to help each other for better advancement.

There are three generic approaches to TQM in higher education. First, there is a customer focus where the ideas of services to student are supported through staff coaching and development, which encouraged student's preference and self-reliance. The second approach is staff focus which pertains to appraise and heighten the share of all members of staff to the potency of an institution's procedure, to the setting of rules and priorities. This implies a blandish management structure and the acceptance of obligation for action determined by working groups. The third approach focuses on service agreement positions and attempt to guarantee compliance to stipulation at sealed access measurable degree of the educational procedures. Evaluation of assignments by faculty within a period of time is an example (Harris, 1994).

Durlabhji and Fusilier (1999) implies that customer authorization in education demands outstanding input from students as well as from business industry that will eventually hire them and this in term will contour education efficiently and extinguish any shadow of the esoteric academic "ivory tower" that is present in business school coursework. It was urged that top leadership is the way to any TQM platform and the compelling force behind success and failure. The TQM platform must be accepted and not pushed on the employees. Right communication, proper education using benchmarking, and explore TQM doctrines and program can raise the success rate (Michael et al., 1997). While Gregory (1996), propose four dimensions of institutional leaderships symbolic, political, managerial and academic in his example of administered leadership for successful change in higher education institutions. Owen (2001) states that "Total and continuous quality development is viewed as a journey which has no real beginning or ending". Thus, it is a constant endeavor for the management to sustain a criterion in the institutions. TQM is a managerial instrument to resolve the issues associated to services as well as tactics in the academic industry and it can conform to the standard the education industry (Venkatraman, 2007; Peat et al., 2005). The accentuate of quality maintenance in higher education has increased as the numbers of students are climbing up and at the same rate, their anticipation are getting high, as they have to settle the tuition fee, so they looking forward for a suitable result (Becket \& Brookes, 2005). Meanwhile, Seymour (1992) has clearly defined the kinds of quality and implements them generally to the higher education institutions. TQM method is viewed as suave beginning of Quality procedures. The key notes in here is to make sure to have the higher management be committed and so that it will be properly initiated and implemented in the institutions quality policy. Though it demands quality time and effort to train and communicate it with the team members it is truly essential, for the implementation of quality procedures and affiliated measures to be successful. Execution of thorough risk analysis and mitigation while contingency plans are established and everything is well documented. Of course, administering of training plan should be as seamless as possible. Superior quality management methods guides in reducing struggles of the modification that is being introduced. Therefore, if TQM techniques are well facilitated and thoroughly implemented, while the basic principles and practices are accepted and executed, TQM methods will be a great help to have a successful development in upgrading the quality of education institutions provide to make their students be more competent and competitive globally to face our fast progressing world. 


\section{Conclusion}

For any constant development effort to be efficient, quality and reliable feedback accumulation is necessary and vital in the assessment procedure of teaching \& learning with the result distinctly characterized and evaluated. It includes procedures that ceaselessly accumulate, examine, and pursue on customer information. TQM is one of the most efficient tools in the field of teaching \& learning criterion in education. The dare is to assure each student will gain from the teaching \& learning procedure by imparting them adequate time, support, encouragement, resources and chance to acquire and hit the set standard of excellence in education in a total quality environment. Based on the empirical literature, it demands having the right characteristics and forthcoming with the supreme target of constant endeavor to develop all field of entrusted obligation. The triumph of institutions depends on their management techniques on how to determine, categorize, examine, and succeed to the efficient approach.

This study discloses that TQM will provide a superior impact on the institutions objective and produce value in improving the economic value. Although the enforcement of TQM brings comprehensive range of alteration in organization, there are deficiencies of approval of this approach in various organizations. But due to deficient identified reason, many institutions do not support TQM methods into their organization. Nevertheless, some organization and institutions already embraced the advantages of TQM implementation on their organization. Organizations will only understand the full advantage of TQM through successful consolidation of various betterment activities, each of which focuses on the fundamental component of the TQM philosophy. An organization contributes various common attribute or acquires usual elements of management, which let them to recognize the real probability of TQM over a period of time. Previous studies revealed that organization can improve their management of higher education by emphasizing values regarding the importance of people, knowledge and continuous improvement (Sherr \& Lozier, 2006). That is also what TQM believes focusing on the right issue to be on the right track to success.

TQM convey issue resolution methods and consistent advancement opportunities, it is efficient use to help institution acquire their highest return on investment. Therefore institution embracing TQM philosophies as a component of their corporate scheme and utilizing any model of Business Excellence for TQM Strategy execution will minimize the cost of its execution and will provide a concrete foundation of necessary increased human function and capabilities, contributive organizational society, best employment of all resources and better procedure. It will alleviate the modification and improvement in an organization given that they will strictly implement TQM methods which will enable them to move towards excellence.

\section{References}

Abdul-Aziz, A. R. (2002). The realities of applying total quality management in the construction industry, Structural Survey. 20(2) 88-96.

Adams, D. (1993). Defining educational quality. Improving Educational Quality Project Publication \#1: Biennial Report. Arlington, VA: Institute for International Research. 
Ariff, M. S. M., Zaidin, N., \& Sulong, N. (2007). Total Quality Management Implementation in Higher Education; Concerns and Challenges Faced by the Faculty. In: $12^{\text {th }}$ International Conference on ISO 9000 \& TQM (12-ICIT)s, Republic of China.

Babbar (1995). Applying total quality management to educational instruction: A case study from a US public university”, International Journal of Public Sector Management, 8(7): 35-55. Barnard, J. (1999). Using total quality principles in business courses: The effect on student evaluations. Business Communication Quarterly. 62(2) 61-73.

Becket, N., \& Brookes, M. (2005). Analyzing quality audits in higher education. Brookes e-learning Journal of Learning and Teaching, 1(2): 1-22.

Becket, N., \& Brookes, M. (2006). Evaluating quality management in university departments. Quality Assurance in Education, 14(2): 123 - 142.

Brookes, M., \& Becket, N. (2007). Quality management in higher education: A review of international issues and practice. International Journal of Quality Standards, 1(1): 85-121.

Burnham (1997) Managing quality in schools: Effective strategies for quality-based school improvement. London: Pearson. 32-33

Cheng, Y. C., \& Tam, W. M. (1997). Multi-models of quality in education. Quality Assurance in Education, 5(1): 22 - 31.

Crosby, P. B. (1979). Quality is Free: The Art of Making Quality Certain. New York: McGraw-Hill.

Crosby, B. P. (1999). Quality without fears: The art of hassle-free management. Belmont: McGraw co.

Durlabhji, S. G. \& Fusilier, M. R. (1999). The empowered classroom: Applying TQM to college teaching. Managing Service Quality, 9(2): 110-115.

Evans. J. R., Dean, W. J. (1999). Total Quality: Management, Organization and Strategy. South-Western Educational Publishing.

Fitzgerald, R. (2004) Total quality management in education. Minuteman career and technical high school. Retrieved from: http://www.minuteman.org/topics/tqm.html

Gaither, N., (1996). Production and Operations Management, Duxbury Press, Cincinnati, OH, pp: 7.

Gallo, A. (2011). Making Sure Your Employees Succeed. Harvard Business Review. Retrieved from: http://blogs.hbr.org/2011/02/making-sure-your-employees-suc.

Gregory, M., (1996). Developing effective college leadership for the management of educational change. Leadership Organization Development Journal, 17(4): 46-51.

Haug, G. (2003). Quality Assurance/Accreditation in the Emerging European Higher Education Area: A possible scenario for the future. European Journal of Education, 38(3): 229-240.

Harris, R. W., (1994). Alien or Ally? TQM, Academic Quality and the New Public Management. Quality Assurance in Education, 2(3): 33-39.

Hoecht, A. (2006). Quality assurance in UK higher education: Issues of trust, control, professional autonomy and accountability. Higher Education, 51, 541-563.

Ishikawa, K. (1985). What is Total Quality Control? The Japanese Way. Translated by David, J. LU, New Jersey: Prentice-Hall, Englewood Cliffs.

Jha, V. S., \& Joshi, H. (2007). Relevance of Total Quality Management (TQM) or Business 
Excellence Strategy Implementation for Enterprise Resource Planning (ERP) - A Conceptual Study. In: 12th International Conference on Information Quality (ICIQ-2007) at MIT, Cambridge, Massachusetts, USA, November 9-11.

Jun, M., Cai, S., \& Shin, H. (2006). TQM practice in maquiladora: Antecedents of employee satisfaction and loyalty. Journal of Operations Management, 24(6), 791-812.

Kelchner, L. (2008). Advantages \& Disadvantages of Total Quality Management Strategies. Chron.com. Retrieved from http://smallbusiness.chron.com/advantages-disadvantages-total-quality-management-strategie s-22160.html.

Lakhal, L., Pasin, F., and Limam, M. (2006). Quality management practice and their impact on performance. International Journal of Quality \& Reliability Management. 23(6): 625-646.

Manktelow, J. (2011). Critical Success Factors: Identifying the Things That Really Matter for Success. Mindtools.com. Retrieved from http://www.mindtools.com/pages/article/new LDR 80.htm

Materu, P. (2007). Higher Education Quality Assurance in Sub-Saharan Africa: Status, Challenges, Opportunities, and Promising Practices. The World Bank, Washington DC.

Michael, R. K., Sower, V. E., \& Motwani, J. (1997). A comprehensive model for implementing total quality management in higher education. Benchmarking for Quality Management and Technology, 4(2): 104-120.

Mizikaci, M. (2009). Total Quality Management in Higher Education. LAP Lambert Academic Publishing AG \& Co. KG. Koln.

Murad A. \& Rajesh K. S. (2010). Implementation of Total Quality Management in Higher Education. Asian Journal of Business Management, 2(1): 9-16.

Napierala, B. (2012). Five important factors in total quality management. Aboutthree.com. Retrieved from http://aboutthree.com/blog/five-important-factors-in-total-quality-management-2.

Owen, R. G. (2001). Organizational Behavior in Education: Instructional Leadership and School Reform, 7th ed. Allyn \& Bacon, Boston, MA.

Owlia, M. S., \& Aspinwall, E. M. (1997). TQM in higher education - A review. International Journal of Quality \& Reliability Management, 14(5): 527-543.

Parasuraman, A., Zeithaml V. A., Berry L. L. (1985). A conceptual model of services quality and its implication for future research. Journal of Marketing, 49(4): 41-50.

Parasuraman, A., Zeithaml V. A., Berry L. L. (1988). Servqual: A multiple-item scale for measuring consumer perceptions of service quality. Journal of Retailing, 64(1): 12-40.

Peat, M., Taylor, C.E. and Franklin, S. (2005), "Re-engineering of undergraduate science curricula to emphasize development of lifelong learning skills". Innovations in Education and Teaching International, 42(2): 135-46.

Rao, S., Ragu, T. S and Solis, L. E. (1997). Does ISO 9000 Have an Effect on Quality Management Practices? An International Empirical Study. Total Quality Management, 8: 335-346.

Rockart, J. F. (1979). Chief executives define their own data needs. Harvard business review, 57(2): 81.

Roffe, I. M., 1998. Conceptual problems of continuous quality improvement and innovation in 


\section{Mll Macrothink}

higher education. Quality Assurance in Higher Education, 6(2): 74-82.

2014, Vol. 4, No. 3

Saad, M., \& Patel, B. (2006). An investigation of supply chain performance measurement in the Indian automotive sector. Benchmarking: An International Journal, 13(2): 36 - 53.

Sangeeta, S., Banwet, D. K., \& Karunes, S. (2004). Conceptualising total quality management in higher education. The TQM Magazine, 16(2): 145-159.

Saraph, J. V., Benson, P. G., \& Schroeder, R. G. (1989). An instrument for measuring the critical factors of quality management. Decision Sciences, 20(4): 810-829.

Seymour, D. T. (1992). On Q: Causing Quality in Higher Education. New York, NY: Macmillan.

Sherr, L. A., \& Lozier, G. G. (2006). Total quality management in higher education. New Directions for Institutional Research, 1991(71): 3-11.

Srikanthan, G. \& Dalrymple, J. (2003). Developing alternative perspectives for quality in higher education. International Journal of Education Management; 17(3): 126-136.

Stanciu, I. (2003), Managementul calit ii totale, Bucureti, Ed. Cartea Universitar "ISO 9000" 2006.

Venkatraman, S. (2007). A framework for implementing TQM in higher education programs. Quality assurance in education, 15(1): 92-112.

Vinni, R. (2011). Total Quality Management and paradigms of public administration, International Public Review, 8(1) 15-23.

Williams. P. (2009). The result of intelligent effort? Two decades in the quality assurance of higher education. Institute of Education, University of London. London.

Yusof, S. M. \& Aspinwall, E. (2000). A conceptual framework for TQM implementation for SMEs. The TQM Magazine, 12(1): 31-37.

Zakuan, N., Muniandy, S., Mat Saman, M. Z., Ariff, M. S. M., Sulaiman, S., \& Jalil, R. A. (2012). Critical Success Factors of Total Quality Management Implementation in Higher Education Institution: A Review. International Journal of Academic Research in Business and Social Sciences, 2(12): 19-32. 